J. Clin. Chem. Clin. Biochem.

Vol. 18, 1980, pp. 631-635

\title{
Hydrolysis of Some Cystine Aminopeptidase and Aminopeptidase Substrates by Human Placental Enzymes after Isoelectric Focusing
}

By Th. Unger

Ernst Rodenwaldt-Institute (Head: OTA Dr. W. Fischer), Koblenz and

\section{H. Struck}

Biochemical and Experimental Division (Head: Prof. Dr. H. Struck) of the II. Department of Surgery (Director: Prof. Dr. W. Schink) of the University of Cologne

(Reccived Junc 6, 1979/April 3, 1980)

Summary: Several cystine aminopeptidase- and aminopeptidaselike activities of mature human placenta were demonstrated by chromatography on CM-Sephadex and subsequent preparative flat bed isoelectric focusing. Enzyme tests were carried out by using a micro modification of the Bratton-Marshall reaction with scven amino acid-p-nitroanilides and one amino acid $\beta$-naphthylamide as substrates.

By this method three main activities were detected; each was nonhomogeneous and capable of hydrolyzing cystine aminopeptidase- as well as aminopeptidase substrates. The substrates benzyl-cystine-p-nitroanilide, cystine di-p-nitroanilide and cystine di- $\beta$-naphthylamide were split by different enzymes. By studying the effects of several effectors or of heating, no enzyme with the properties described in the literature for serum cystine aminopeptidase could be unequivocally demonstrated.

The results reported here suggest that serum cystine aminopeptidase - in contrast to placenta cystine aminopeptidase - is either altered severely in its structure or that it represents a multiplicity of enzymes, which attack "specific" substrates and are therefore jointly manifested as cystine aminopeptidase.

Hydrolyse einiger Substrate für Cystinaminopeptidase und Aminopeptidase durch Enzyme aus der Placenta vom Menschen nach isoelektrischer Fokussierung

Zusammenfassung: Durch Chromatographie an CM-Sephadex und nachfolgende präparative isoelektrische Fokussierung lassen sich in der reifen menschlichen Placenta unterschiedliche Cystinaminopeptidase- und Aminopeptidase-Aktivitäten nachweisen. Die Enzymtests wurden mit einer Mikro-Modifikation der Bratton-Marshall-Reaktion und sieben Aminosäure-p-nitroaniliden sowie einem Aminosäure- $\beta$-naphthylamid als Substrate durchgeführt.

Durch diese Methodik wurden drei Hauptaktivitäten nachgewiesen, die selbst wiederum inhomogen sind und sowohl Cystinaminopeptidase- als auch Aminopeptidase-Substrate hydrolysieren können. Die Substrate Benzyl-cystin-pnitroanilid, Cystin-di-p-nitroanilid und Cystin-di- $\beta$-naphthylamid wurden von unterschie dlichen Enzymen gespalten. Auch nach Zugabe verschiedener Effektoren oder Hitzeexposition konnte keine Enzymaktivität entdeckt werden, für die die in der Literatur beschriebenen Eigenschaften der Serum-Cystinaminopeptidase ohne Einschränkungen zutreffen.

Die hier berichteten Ergebnisse legen die Annahme nahe, daß die Serum-Cystinaminopeptidase gegenüber der Placenta-Cystinaminopeptidase entweder stark in ihrer Struktur verändert ist oder daß mit den meisten "spezifischen“ Substraten auch im Serum eine Vielzahl von Enzymen gemessen wird, die insgesamt als Cystinaminopeptidase imponiert. 


\section{Introduction}

The placenta is said to be the source of serum enzymes which inactivate the labour-inducing posterior pituitary hormone oxytocin by splitting an amino terminal cysteinyl tyrosine bond (1). Following the introduction of amino acid $\beta$-naph thylamides and amino acid $p$-nitroanilides as ostensibly specific substrates, the properties of this serum oxy tocinase or cystine aminopeptidase (EC 3.4.11.3) were extensively analyzed and are now well known (for review see 1.c. (2)). It was also shown that the assay of serum cystine aminopeptidase activity with these substrates reveals the presence of other aminopeptidases of so far unknown origin and properties, in addition to true oxy tocinase (3). Enzyme activities which split substrates specific for oxy tocinase are very low in normal serum (4). When such unspecific activities are measured during pregnancy, they might therefore also originate from the placenta. Hydrolysis of cystine aminopeptidase substrates by enzymes of human placenta has - in contrast to the hydrolysis of this substrate by serum activities - not yet been systematically investigated. In the course of our ongoing studies on proteolytic enzymes of this organ $(5,6)$, we therefore partly enriched such activities from mature human placenta, and measured their action upon several amino acid $p$-nitroanilides and cystine di- $\beta$-naphthylamide, with and without addition of effectors and with exposure to heat.

We also hope to improve our understanding of serum cystine aminopeptidase.

\section{Experimental}

\section{Materials}

The substrates used are listed in table 1.

Alanine $p$-nitroanilide, cystine di-p-nitroanilide, glycine $p$-nitroanilide and phenylalanine $p$-nitroanilide were from Merck, Darmstadt; benzyl-cysteine $p$-nitroanilide and leucine $p$-nitroanilide were purchased from Boehringer, Mannheim; cystine di- $\beta$-naph thylamide was a preparation from Serva, Heidelberg.

Tab. 1. Relative hydrolysis rates of several cystine aminopeptidaseand aminopeptidase substrates after focusing (hydrolysis of alanine $p$-nitroanilide in peak $\mathrm{I}$ taken as 1.00 . For further details see text.

\begin{tabular}{llll}
\hline Substrate & Peak I & Peak II. . Peak III \\
\hline Alanine $p$-nitroanilide & 1.00 & 0.46 & 0.28 \\
Leucine $p$-nitroanilide & 0.98 & 0.54 & 0.43 \\
Lysine $p$-nitroanilide & 0.41 & 0.35 & 0.17 \\
Benzyl-cysteine $p$-nitroanilide & 0.23 & 0.26 & 0.05 \\
Phenylalanine $p$-nitroanilide & 0.20 & 0.16 & 0.07 \\
Glycine $p$-nitroanilide & 0.10 & 0.04 & 0.02 \\
Cystine di-p-nitroanilide & 0.08 & 0.06 & 0.03 \\
Cystine di- $\beta$-naphthylamide & 0.01 & 0.07 & 0.00 \\
\hline
\end{tabular}

Tab. 2. Relative hydrolysis rates after addition of effectors (leucine $p$-nitroanilide as general substrate). Remaining activities are expressed as fractions of the activities of controls without addition of effectors.

\begin{tabular}{llll}
\hline Effector & Peak I & Peak II & Peak III \\
\hline Control & 1.00 & 1.00 & 1.00 \\
$\mathrm{Ca}^{++}$ & 1.05 & 1.10 & 1.05 \\
$\mathrm{Co}^{++}$ & 1.10 & 1.15 & 1.00 \\
$\mathrm{Mg}^{++}$ & 1.00 & 1.10 & 1.05 \\
$\mathrm{~Pb}^{++}$ & 0.05 & 0.10 & 0.05 \\
$\mathrm{Zn}^{++}$ & 1.00 & 1.30 & 1.05 \\
$\epsilon$-aminocaproic acid & 1.05 & 1.20 & 1.25 \\
Cysteine & 1.05 & 1.10 & 1.10 \\
Dithioery thritol & 1.10 & 1.25 & 1.05 \\
Ethylene diaminetetraacetate & 0.95 & 0.90 & 0.90 \\
$p$-hydroxymercuribenżoate & 0.95 & 0.75 & 0.30 \\
Iodacetamide & 1.10 & 1.15 & 1.00 \\
$L$-methionine & 0.70 & 0.90 & 1.00 \\
$D$-penicillamine & 0.90 & 1.00 & 1.00 \\
Puromycin & 0.15 & 0.45 & 0.70 \\
Aprotinin & 1.10 & 1.25 & 1.10 \\
\hline
\end{tabular}

The effectors used are listed in table 2.

$\epsilon$-aminocaproic acid, 4-hydroxymercuribenzoate, ethylene diamine tetraacetate, iodacetamide and $D$-penicillamine were from Serva, Heidelberg; puromy cin was from Boehringer, Mannheim, aprotinin from Bayer, Leverkusen. All the other effectors were from Merck, Darmstadt.

Full term placentae without macroscopically visible pathological changes served as enzyme sources. They were freed from remaining blood, washed with tap water and frozen at $-20^{\circ} \mathrm{C}$ until they were worked up.

\section{Methods}

The enzymes were enriched prior to isoelectric focusing by a procedure comprising elution in ammonium acetate solution $0.1 \mathrm{~mol} / \mathrm{l}$, ammonium sulfate precipitation up to 0.80 saturation, dialysis against ammonium acetate buffer $0.1 \mathrm{~mol} / 1 \mathrm{pH} 6.0$, chromatography on a CM Sephadex C 50 column, previously equilibrated and eluted with the same buffer, and freeze drying of the protein which was not bound on to the exchanger. The procedure is described in more detail in l.c. (6).

Subsequently, $500 \mathrm{mg}$ of the dry material were mixed with $6 \mathrm{ml}$ of Servalyt pH 4-6 (Serva 42904) and $94 \mathrm{ml}$ of Ultrodex $4 \mathrm{~g} / 100 \mathrm{ml}$ (LKB, Munich), swollen in double distilled water. A plate of $24.5 \times 10.8 \mathrm{~cm}$ was cast and focused for $7 \mathrm{~h} \mathrm{at}$ $20 \mathrm{~W}$ power under cooling with tap water in a double chamber (Desaga, Heidelberg).

After focusing the gel was cut into 30 fractions and transferred into plastic columns (LKB, Munich). Elution was carried out by addition of $2 \mathrm{ml}$ double distilled water to each fraction; $\mathrm{pH}$ was measured in these eluates. Then a second elution of the fractions was performed by adding of $3 \mathrm{ml}$ Tris- $\mathrm{HCl}$ buffer $0.2 \mathrm{~mol} / 1$ $\mathrm{pH}$ 7.5. Protein concentrations in the eluates were determined by measurement of absorbance at $280 \mathrm{~nm}$ after ten-fold dilution.

The enzyme assay was based on our micro modification of the Bratton-Marshall reaction as described elsewhere (7).

Enzyme samples were incubated in Tris- $\mathrm{HCl}$ buffer $0.20 \mathrm{~mol} / \mathrm{l}$ (total incubation volume $800 \mu \mathrm{l}$ ) $\mathrm{pH} \mathrm{7.5}$; tests were started by adding of $10 \mu \mathrm{l}$ substrate $0.1 \mathrm{~mol} / 1$ in dimethyl sulfoxide.

In order to check the action of some effectors, $200 \mu \mathrm{l}$ samples from the enzymatically most active fractions of the focusing experiments were pre-incubated for $5 \mathrm{~min}$ at $37^{\circ} \mathrm{C}$ with $100 \mu \mathrm{l}$ each of the effector stock solutions listed in table 2 . The concentrations of the stock solutions were uniformly $10 \mathrm{mmol} / 1$; aprotinin was used undiluted. For these effector experiments enzyme tests were started by adding $10 \mu$ leucine $p$-nitroanilide solution $0.1 \mathrm{~mol} / 1$ in dimethylsulfoxide as a general substrate. 
After stopping the test incubation, the remaining activities were measured and expressed as fractions of the controls without addition of effectors.

Heating experiments: Samples from the enzymatically most active peak fractions were pre-incubated for $30 \mathrm{~min}$ at $56{ }^{\circ} \mathrm{C}$ prior to the enzyme assays and followed by the tests with leucine $p$-nitroanilide as substrate as described above. Remaining activities were expressed again as fractions of the controls without heating.

\section{Results}

\section{Focusing}

The results of the preparative isoelectric focusing experiments are presented in figure 1-3. All data are arithmetic means taken from double determinations.

In the main the focusing experiments yielded three peaks with the isoelectric points 3.8-4.3 (peak I), 4.8-5.1 (peak II) and 5.4-5.6 (peak III). The highest hydrolysis rates were measured with alanine $p$-nitroanilide and leucine $p$-nitroanilide as substrates, followed by lysine $p$ nitroanilide, benzyl-cysteine $p$-nitroanilide, phenylalanine $p$-nitroanilide, glycine $p$-nitroanilide, cystine di-p-nitroanilide and cystine di- $\beta$-naphthylamide.

It is clearly evident from the figures that the activities in the actual peaks do not represent homogeneous enzymes; in a future paper we will deal with the further differentiation of these activities by gel chromatography. If the measured hydrolysis rates are expressed for an uniform enzyme quantity of $200 \mu$ l the resulting relative activities can be compared as shown in table 1 .

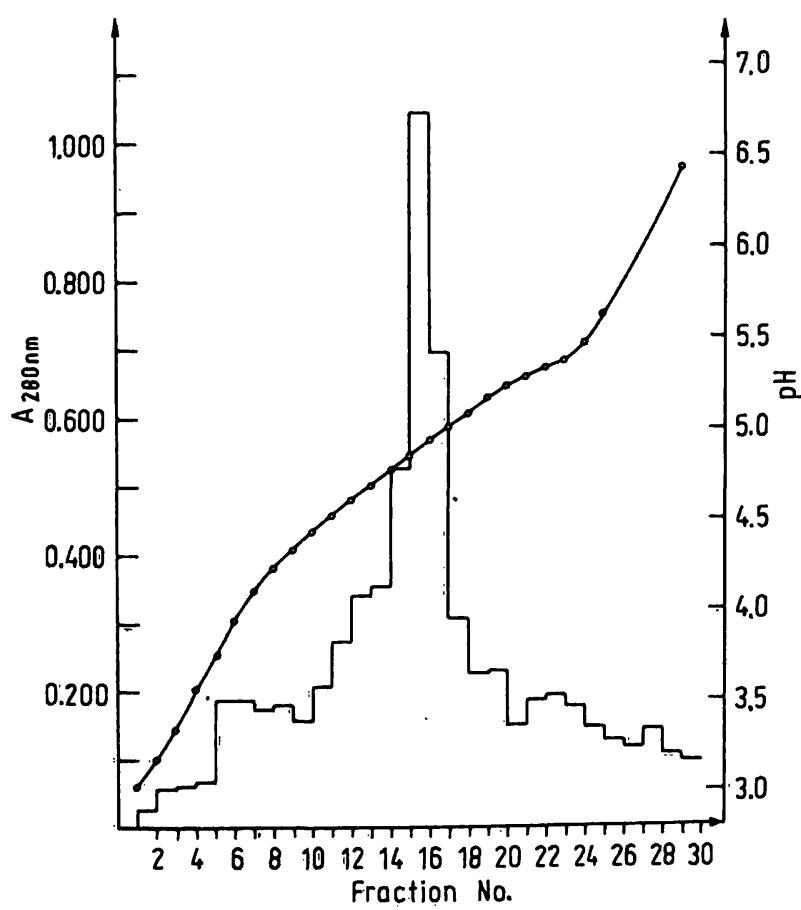

Fig. 1. Flat bed isoelectric focusing of human placental enzymes (500 mg protein: ampholy tes pH 4-6; $20 \mathrm{~W} ; 7 \mathrm{~h}$ ) after chromatography on CM Sephadex C 50.

Abscissa: fraction numbers; left ordinate: absorption at $280 \mathrm{~nm}(-)$ after ten-fold dilution; right ordinate: $\mathrm{pH}$ values $(0-0)$. For further details see text.

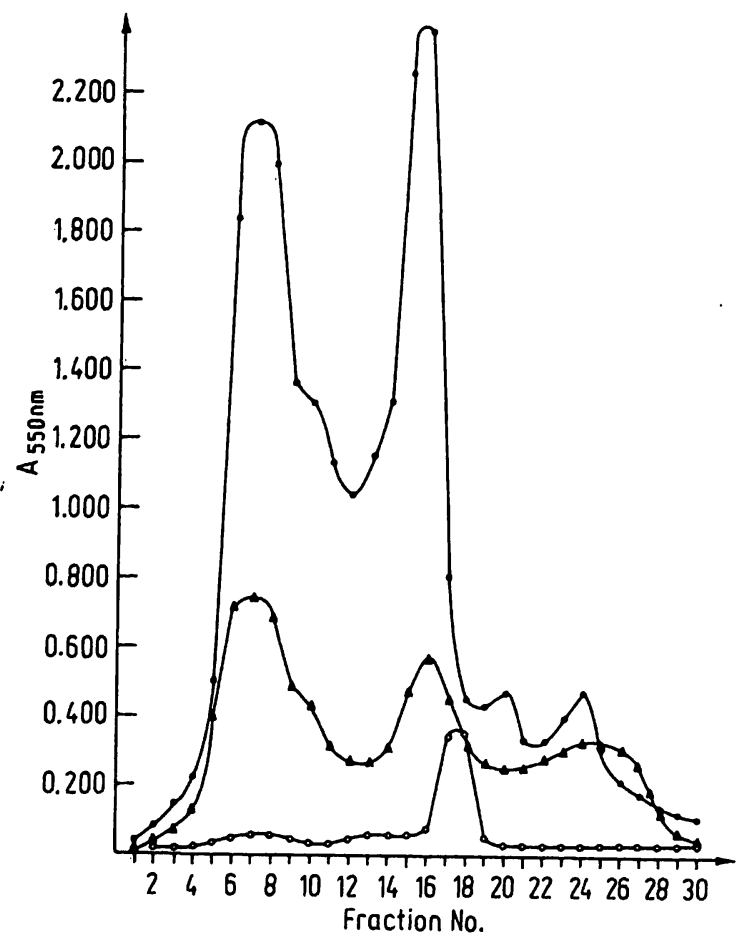

Fig. 2. Hydroly sis of cystine aminopeptidase substrates by placental enzymes after isoelectric focusing. Enzyme $(200 \mu \mathrm{l})$ tests were carried out uniformly at $30 \mathrm{~min} / 37^{\circ} \mathrm{C}$.

Abscissa: fraction numbers; ordinate: absorptions at $550 \mathrm{~nm}$.

$\longrightarrow$ Benzyl-cysteine $p$-nitroanilide

$\leadsto$ Cystine di-p-nitroanilide

$\multimap$ Cystine di- $\beta$-naph thylamide

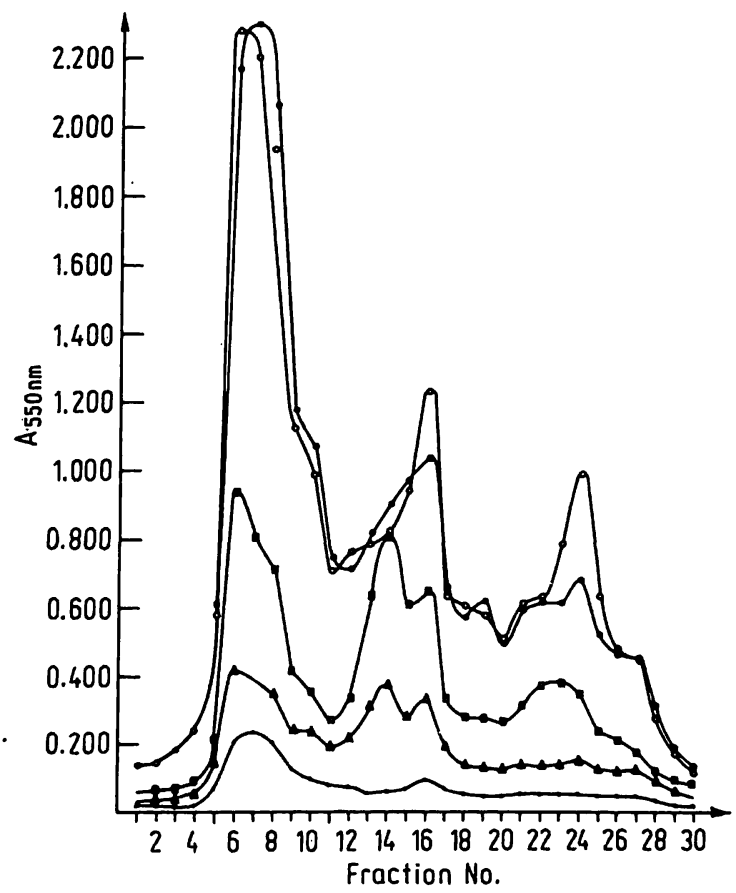

Fig. 3. Hydrolysis of aminopeptidase- and arylamidase substrates by placental enzymes $(50 \mu \mathrm{l})$ after isoelectric focusing. Test conditions as men tioned for fig. 2.

$\propto$ Glycine $p$-nitroanilide

$\longrightarrow$ Alanine $p$-nitroanilide

- Lysine $p$-nitroanilide

$\propto$ L Leucine $p$-nitroanilide

$\longrightarrow$ Phenylalanine $p$-nitroanilide 


\section{Substrate specificity}

The distribution of hydrolysis rates shows that most of the substrates used here are of relative poor specificity; there are only small differences between classic cystine aminopeptidase substrates on the one hand and simple aminopeptidase substrates on the other. Peak I contains considerable activities towards typical arylamidase- and aminopeptidase substrates alanine $p$-nitroanilide, leucine $p$-nitroanilide, phenylalanine $p$-nitroanilide as well as cystine aminopeptidase substrates (benzyl-cysteine $p$ nitroanilide and cystine di- $p$-nitroanilide), but there is practically no activity towards cystine di- $\beta$-naphthylamide. Peak II contains the strongest benzyl-cysteine $p$-nitroanilide and cystine di- $\beta$-naphthylamide hydrolyzing activities, but it is clear that the cystine di- $\beta$-naphthylamide cleaving enzyme is by no means identical with the former one. By using a more advanced focusing technique they indeed are quite well separated (paper in preparation). In peak III, mainly leucine $p$-nitroanilide and alanine $p$-nitroanilide are hydrolyzed, but there are still activities towards benzyl-cysteine $p$-nitroanilide and cystine di- - -nitroanilide, whereas the hydrolysis of lysine $p$-nitroanilide shows in irregular pattern, which is distributed over a wide $\mathrm{pH}$ range.

To summarize, one can say that the substrates benzylcysteine $p$-nitroanilide, cystine di- $p$-nitroanilide and cystine di- $\beta$-naphthylamide are split to a great extent by different enzymes.

\section{Effectors}

The results of the effector experiments are given in table 2.

Of the tested divalent cations, only $\mathrm{Pb}^{++}$inhibits all activities, whereas $\mathrm{Zn}^{++}$shows a clear activating capacity upon the enzymes in peak II. Cysteine or ethylenediamine tetraacetic acid are more or less inefficient: $p$-hydroxymercuribenzoate inhibits the enzymes of the peaks II and III, which leads to the conclusion that SH-enzymes are incorporated there. These, however, can only be activated to a small extent by addition of cysteine or dithioerythritol. Methionine inhibits the enzymes of peak I weakly, whereas puromycin represents the most efficient inhibitor after $\mathrm{Pb}^{++}$, especially for the activities of the peaks I and II.

\section{Heating experiments and addition of methionine}

After pre-incubation of the test mixture at $56^{\circ} \mathrm{C}$ (see "Materials and Methods") remaining activities of 0.83 (peak I), 0.37 (peak II) and 0.16 (peak III) were measured, whereas values of 0.70 (I) and 1.00 (III) were found (leucine $p$-nitroanilide as substrate) when heating was performed in the presence of $L$-methionine.

\section{Discussion}

Serum cystine aminopeptidase (EC 3.4.11.3) is not inhibited by $L$-methionine $(8,9)$, but strongly inhibited by ethylenediamine tetraacetic acid (10), $p$-chloromercuribenzoate (11) and $\mathrm{Pb}^{++}(12)$; it is activated by $\mathrm{Co}^{++}$ and $\mathrm{Zn}^{++}(13)$, is sensitive to heat $(8,9)$ and hydrolyzes cystine di- $p$-nitroanilide (14), benzyl-cysteine $p$-nitroanilide $(15,16)$ and cystine di- $\beta$-naphthylamide (1) ostensibly in a specific way, in addition to leucine $p$ nitroanilide and glycine $p$-nitroanilide (14). According to Yman (17) its isoelectric point lies at $\mathrm{pH} 3.7$, but can be raised to $\mathrm{pH} 4.5$ by desialiation. In polyacrylamide electrophoresis one can detect - subject to the chosen test conditions - one or two bands which are named cystine aminopeptidase 1 and cystine aminopeptidase $2(18,19)$.

In contrast to our expectations that one or two cystine aminopeptidase would also be found in placenta, focusing led to three main peaks, which were nonhomogeneous. This means that there is a multiplicity of enzymes which can hydrolyze classic cystine aminopeptidase substrates as well as aminopeptidase substrates, moreover, there is no distinct relationship between the hydrolysis rates of various "specific" cystine aminopeptidase substrates. An enzyme contained in peak II, however, resembles the slowly migrating sialic acid-free cystine aminopeptidase 2 of serum, since it shows - in contrast to other activities - a certain specificity for the first synthetic cystine aminopeptidase, substrate cystine di- $\beta$-naphthylamide (1).

It is also possible to differentiate between arylamidases and cystine aminopeptidase of placental origin, according to Oya et al. (8), by studying the divergent reactions of these enzymes after addition of $L$-methionine and heating; but even on addition of $L$-methionine, ethylenediamine tetraacetic acid, hydroxymercuribenzoate and $\mathrm{Pb}^{++}$or exposure to heat, an enzyme corresponding directly to serum cystine aminopeptidase could not be unequivocally detected.

Hence, in the present work on placental hydrolytic enzymes, the substrates were not hydrolyzed by oxytocinase-cystine aminopeptidase. This especially applies to benzyl-cysteine $p$-nitroanilide, which was claimed to be specific for serum cystine aminopeptidase (16); moreover, it cannot be hydrolyzed "ex definitione" by aminopeptidases, because of the substitution at the amino terminal of cysteine.

The results reported here lead to the conclusion that serum cystine aminopeptidase is either altered severely in its structure, or that it represents a multiplicity of enzymes, which attack "specific" substrates and are therefore jointly manifested as cystine aminopeptidase. At any rate one can suppose that serum enzymes obtained from placenta would show activity towards the mentioned substrates as well as glycine $p$-nitroanilide and lysine $p$-nitroanilide, which are hardly split by arȳamidases of normal serum (4). Until the problem as to which enzymes split oxytocin and which split cystine 
aminopeptidase substrates is solved, it might be useful for reasons of specificity and comparability with older investigations - to go back to the primary substrate cystine di- $\beta$-naph thylamide for assaying serum cystine aminopeptidase. Investigations on this problem are under way.

\section{References}

1. Tuppy, H. \& Nesvadba, H. (1957) Mschr. Chem. 88, 977-988.

2. Morton, D. B. (1977) in Proteinases in mammalian cells and tissues (Barrett, A. J. ed.) pp. 488-491. North Holland, Amsterdam-New York.

3. Tiderström, G. \& Heinegard, D. (1978) Clin. Chim Acta 88, 293-304.

4. Unger, Th. \& Struck, H. (1977) Clin. Chim. Acta 78, 113120.

5. Unger, Th. \& Struck, H. (1977) Arch. Gynäkol. 222, 311 318.

6. Unger, Th. \& Struck, H. (1978) Arch. Gynäkol. 225, 227235.

7. Unger, Th., Nagelschmidt, N. \& Struck, H. (1979) Eur. J. Biochem. 97, 205-211.

8. Oya, M., Yoshino, M. \& Asano, M. (1974) Experientia 30, 985-986.

9. Mizutani, S., Yoshino, S. \& Oya, M. (1976) Clin. Biochem. 9, 16-18.

10. Semm, K. (1958) Arch. Gynäkol. 191, 57-64.

\section{Acknowledgement}

We thank Mr. H. G. Scholder for his excellent technical assistance.
11. Hooper, K. C. (1960) in Polypeptides Which Effect Smooth Muscles and Blood Vessels (Schacter, M.ed.) pp. 83-94. Pergamon Press, Oxford - New York.

12. Hanson, H. (1966) in Hoppe-Seyler/Thierfelder, Handbuch der physiologisch- und pathologisch-chemischen Analyse, Vol. VI C, pp. 219-227. Springer, Berlin - Heidelberg New York.

13. Werle, E. \& Semm, K. (1956) Arch. Gynäkol. 187, 449-457.

14. Tuppy, H., Wiesbauer, U. \& Wintersberger, E. (1962) HoppeSeyler's Z. Phy siol. Chem. 329, 278-288.

15. Hanson, H. \& Mannsfeldt, H. G. (1971) Nova Acta Leopoldina 200, 9-22.

16. van Oudheusden, A. P. M. (1972) J. Clin. Chem. Clin. Biochem. 10, 345-346.

17. Yman, L. (1970) Acta Pharm. Suecica 7, 29-36.

18. Page, E. W., Titus, M. A., Mohun, G. \& Glendening, M. B. (1961) Am. J. Obstet. Gynecol. 82, 1090-1095.

19. Sjöholm, I. \& Yman, L. (1966) Acta Pharm. Suecica 3, 389-396.
Prof. Dr. Hansjürgen Struck II. Chirurg. Lehrstuhl der Universität zu Köln Biochemische Abteilung Ostmerheimer Str. 200

D-5000 Köln 91

Senior Award

der National Academy of Clinical Biochemistry

für Johannes Büttner

Anläßlich des Fourth Annual Meeting der National Academy of Clinical Biochemistry in Boston, Mass., hielt Herr Professor Dr. Dr. Johannes Büttner, Geschäftsführender Direktor des Instituts für Klinische Chemie der Medizinischen Hochschule Hannover und einer der Herausgeber dieser Zeitschrift, am 19. Juli 1980 den Festvortrag „From Chemistry of Life to Chemistry of Disease: The Rise of Clinical Biochemistry " und wurde in Anerkennung seiner wissenschaftlichen Originalität, Initiative und seiner Beiträge zum Fortschritt der Klinischen Biochemie mit dem Senior Award ausgezeichnet sowie zum Ehrenmitglied ernannt. 
